\title{
CONTROL OF SEDIMENT EXPORT FROM THE FoREST ROAD PRISM
}

\author{
J. M. Grace III
}

\begin{abstract}
The effectiveness of four road turn-out ditch treatments (vegetation, rip-rap, sediment fences, and settling basins) in reducing sediment export to the forest floor was evaluated. These four runoff control methods are commonly prescribed to control forest road runoff and sediments. The study utilized runoff samplers, runoff diversion walls, sediment filter bags, and erosion stakes to evaluate runoff concentration reductions through the treatments and sediment export downslope of the treatments. Settling basin, sediment fence, and vegetation treatments had no significant differences in runoff concentration reductions, which averaged more than $40 \%$. The rip-rap was significantly less effective at reducing runoff concentration than were either the vegetation or sediment fence. The sediment basins were very effective during smaller storm events, but not during the largest storms, when they overflowed. The sediment basin exported the least amount of smaller-sized sediment that is likely to be delivered to stream systems.
\end{abstract}

Keywords. Forest roads, Soil erosion, Conservation practices, Surface runoff.

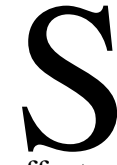
oil erosion and eventual stream sedimentation adversely affect the nation's water quality. Eroded sediment can carry nutrients and pesticides, which degrade water quality and affect aquatic life. The effects of human disturbances on soil erosion and sedimentation are major concerns in land management in the U.S. Special attention has been given to sediment transport from non-point sources resulting from management activities on forested lands.

Forested lands have minimal erosion and sedimentation when there is minimal soil disturbance from forest operations. The increased surface cover from trees in combination with protection from raindrop impact by forest litter negates the damaging effects of rainstorm energy. A different condition is encountered once the vegetation and surface litter are disturbed by forest operations, resulting in accelerated erosion and degradation of stream water quality (Grace, 1998; Reinhart et al., 1963). Forest roads have been emphasized as major contributors of potentially detrimental impacts (Binkley and Brown, 1993; Reid and Dunne, 1984). They account for as much as $90 \%$ of all erosion losses on forested lands (Hoover, 1952; Megahan, 1972; Patric, 1976).

High levels of soil erosion can occur following road construction and maintenance, which disturb forest cover and the forest floor (Grace et al., 1998; Grace, 1999). Forest floor disturbance can accelerate typically negligible forest erosion rates of $0.30 \mathrm{t} / \mathrm{ha}$ by more than a hundred-fold. Forest roads have clearly been defined as the major contributor of

Article was submitted for review in October 2000; approved for publication by the Emerging Areas Division of ASAE in April 2002. Presented at the 1999 ASAE Annual Meeting as Paper No. 995048.

The author is John McFero Grace III, ASAE Member, Research Engineer, USDA Forest Service, G.W. Andrews Forestry Sciences Lab, Southern Research Station, SRS-4703, 520 Devall Drive, Auburn, AL 36830; phone: 334-826-8700; fax: 334-821-0037; e-mail: jmgrace@fs.fed.us. sediment transport to streams from forestlands (Anderson et al., 1976; McClelland et al., 1999; Packer, 1967; Patric, 1976). Several factors contribute to the increased erosion potential of forest roads: (1) removal of surface cover, (2) concentrated flow in ditches, (3) interception of subsurface flow, (4) destruction of the natural soil structure, (5) increased slopes, and (6) compaction. The combination of these factors greatly increases potential for soil detachment and transport and requires special design considerations to reduce environmental impacts on surface water quality.

The environmental impacts of forest roads are largely dependent on site characteristics, topography, and geographical area. More specifically, erosion and sedimentation from roads vary depending on soil characteristics, climatic factors, and watershed hydrology. Swift (1985) found that roadside slopes and ditches accounted for the majority of sediment produced from the road prism in a study in the southern Appalachians. Bare roadside slopes and ditches in Swift's study produced greater than 150 t/ha during a 4-month winter period. Grace et al. (1997) found that bare roadside slopes alone produced slightly greater than 40 t/ha over a 6-month period. The roadside ditch is considered a major area of concern in mitigating erosion losses from the road prism in most geographical regions.

Most state Best Management Practices (BMPs) recommend the installation of some form of erosion control techniques to reduce sediment exported from the road prism. Alabama's BMPs suggest the installation of water diversion techniques such as turn-out ditches, water bars, and broadbased dips at the time of road construction to minimize sediment export (Alabama Forestry Commission, 1993). BMPs state that adequate drainage is one of the most important factors in controlling sediment movement from the road system. Some state BMPs are more detailed and aggressive; Kentucky, for example, passed a law in 1998 to promote good stewardship on forestland by requiring that loggers and operators use appropriate BMPs during timber harvest. 
Haupt (1959), in a study of sediment flow distances downslope of non-point sources, found flow distances ranged from 1 to $113 \mathrm{~m}$. The investigator concluded that sediment transport distances from a road embankment into a buffer zone were affected by four factors: the slope obstruction index, slope length, road gradient, and crossditch interval squared. This work resulted in an equation for determining safe filter strip widths based on these four factors. An alternative filter strip width equation was proposed by Swift (1986) based on his research relating to brush barriers and type of drainage structure. The sediment transport distances without vegetation ranged from 11 to $96 \mathrm{~m}$, with shorter distances below vegetated slopes. The final equation presented by Swift's research was:

$$
\text { slope distance }(\mathrm{ft})=43+1.39 \times(\text { slope percent })
$$

Road designs that consider environmental impacts have a common principle: directing water away from the roadway with a non-erosive velocity. Many authors have suggested criteria for such designs, emphasizing water control and drainage structures, which are two major influences on soil erosion and sedimentation (Cook and Hewlett, 1979; Gardner, 1978; Hewlett and Douglass, 1968; Murphy, 1985; Packer, 1967; Swift, 1985; Weitzman and Trimble, 1952). Diversion of surface water into filter strips or other dispersion areas reduces runoff volume and velocity and thereby directly influences soil detachment and transport by reducing the erosive energy of runoff water (Brinker, 1993; Trimble and Sartz, 1957). Typical design features utilized to remove water from the road prism include broad-based dips, turn-outs, culverts, earthen berms, and outsloping. However, there is little research on the erosion control efficacy of many of the above-mentioned design features.

Historically, most forest roads were designed with the primary goal of providing access to areas for management prescriptions, with little regard to environmental impacts. Currently, the concern in forest road research is the design of road systems that consider three major objectives: environmental sensitivity, aesthetics, and sustainability. Removing water from the road system with minimal soil movement and preventing sediment from being exported to stream channels are two goals for improved road designs. The most important method to accomplish these goals is to disperse flow, thus reducing erosive energy of the runoff water.

The roadside ditch is a critical area in forest road management because it serves as a zone of flow concentration from the traveled way, cutslope, and upland forest. The roadside ditch has increased erosion potential due to large volumes of water at high velocities. Reducing sediment export from the road prism will likely reduce the amount of sediment that reaches streams, which causes detrimental effects to aquatic life. It is hypothesized that the roadside ditch can be utilized to mitigate sediment export from the forest road system, thereby decreasing sediment transport distances downslope. Based on the above hypothesis, ditch erosion control techniques will be a major element in the reduction of environmental impacts of forest roads on forest lands.

\section{OBJECTIVES}

This investigation evaluated the effectiveness of four ditch turn-out treatments in reducing sediment export to the forest floor, in order to supplement or improve current road BMPs. The treatments were compared based on the sediment filtered from each associated treatment. The purpose of this experiment was to test the hypothesis that there are no differences in the filtering capacity of the following four roadside erosion control techniques: (1) vegetation, (2) riprap, (3) sediment fences, and (4) settling basins.

\section{Materials ANd Methods}

The study site was a one-mile section of access road on the Tuskegee National Forest in Macon County near Tuskegee, Alabama. Long-term average annual precipitation for the Tuskegee area is $1300 \mathrm{~mm}$, most of which is rainfall. The 10-year, 24-hour storm for the area is given as $165 \mathrm{~mm}$. Rainfall amount and intensity, ambient temperature, and soil moisture were recorded by a weather station located on site. Runoff volumes in turn-out sections were estimated based on runoff emanating from road sections, taking into account infiltration rates for each associated road section and roadside ditch.

Soil on the study site is a Norfolk loamy sand, ranging from $6 \%$ to $12 \%$ slope. Norfolk soils are characterized by a 15-cm deep, gray, loose, sand surface layer. The upper subsoil layer is light brownish-yellow loamy sand, and the lower soil layer, at a depth of $1.1 \mathrm{~m}$, is yellow friable sandy clay. The forest road evaluated in this study was reconstructed, during a two-week period in August 1997, to incorporate proper turn-out design and spacing. The crowned road with ditching had originally been constructed 20 years earlier for forest management activities.

Road turn-out ditches with similar topography, road design, soils, and drainage were selected for this investigation. Three replicates of four sediment control techniques were used in this experiment: (1) vegetation, (2) rip-rap, (3) sediment fences, and (4) settling basins (fig. 1). Turn-out ditch spacing and construction/re-construction followed specifications currently recommended by Alabama's Best Management Practices and used by the National Forests of Alabama (table 1). Turn-out ditches were V-shaped with a minimum cross-sectional width of $1.2 \mathrm{~m}$ and depth varying according to surrounding topography. Turn-out ditch slopes were limited to $2 \%$ to $4 \%$ grades.

Ditch treatments were hand-seeded with a mixture of Pensacola bahiagrass (Paspalum notatum) at $22.5 \mathrm{~kg} / \mathrm{ha}$, annual lespedza (Lespedza cuneata) at $5.6 \mathrm{~kg} / \mathrm{ha}$, white clover (Trifolium repens) at $11.2 \mathrm{~kg} / \mathrm{ha}$, and Kentucky 31 fescue (Festuca arundinacea) at $28.1 \mathrm{~kg} / \mathrm{ha}$. Treatment areas were mulched by hand with fescue hay at a rate of 4.5 t/ha and fertilized with 13-13-13 fertilizer at a rate of 1.0 $\mathrm{t} / \mathrm{ha}$. Treatments were applied within the treatment area, $3 \mathrm{~m}$ $\times 3.5 \mathrm{~m}$, with the $3-\mathrm{m}$ length between inlet and outlet sampling points (fig. 2). Vegetation treatments consisted solely of the seeding and mulching scheme mentioned above applied within the treatment area. Settling basins were designed on the basis of expected runoff from the road prism drainage area supporting the turn-out ditch. Settling basins were designed to hold $38 \mathrm{~mm}$ ( 25\% of 10-year, 24-hour storm) of runoff from drainage areas using the equation:

$$
V=A \times d
$$




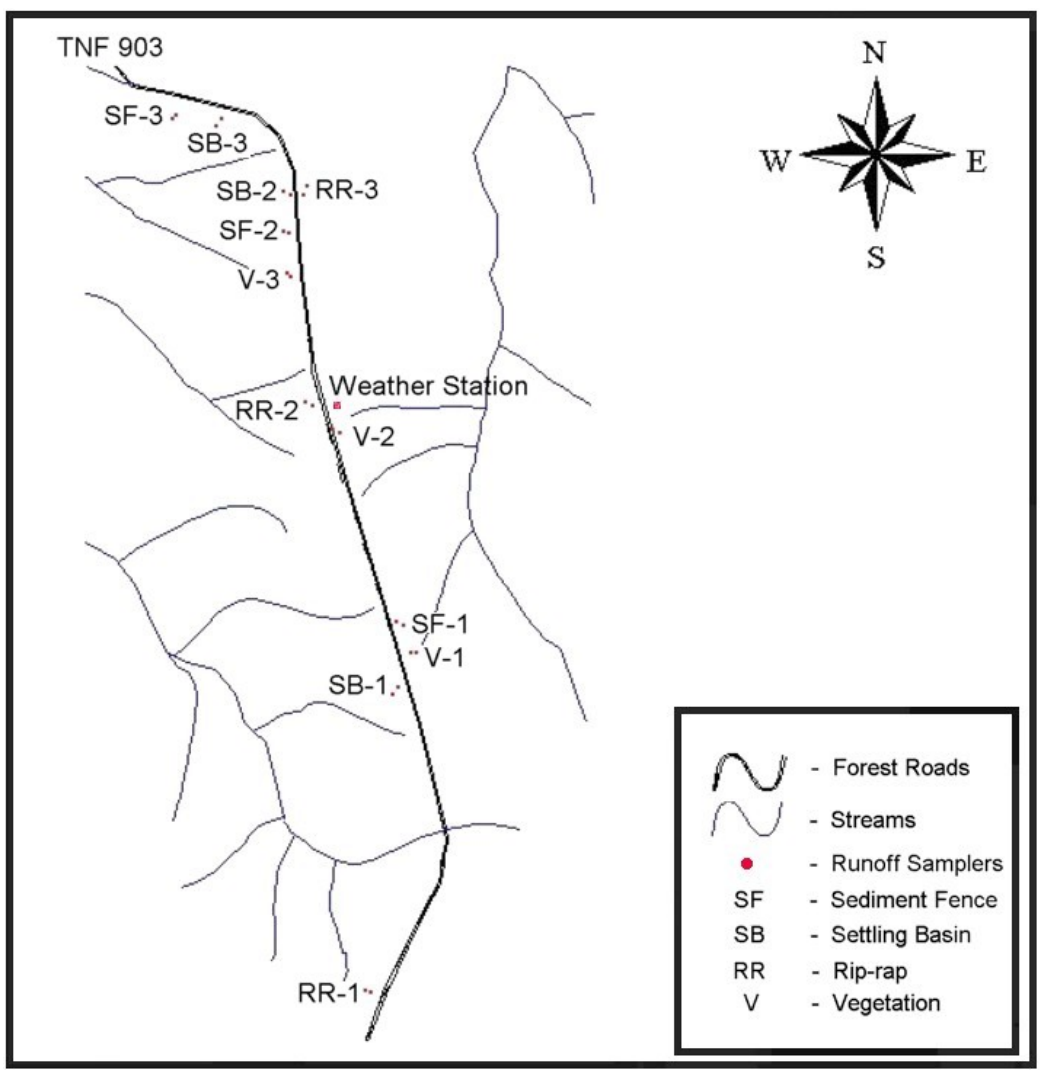

Figure 1. Experimental design and field layout for the Tuskegee study.

Table 1. Recommended spacing for turnout ditches and broad-based dips.

\begin{tabular}{ccc}
\hline $\begin{array}{c}\text { Road Gradient } \\
(\%)\end{array}$ & $\begin{array}{c}\text { Turn-Out Ditch } \\
(\mathrm{m})\end{array}$ & $\begin{array}{c}\text { Broad-Based Dip }^{[\mathrm{b}]} \\
(\mathrm{m})\end{array}$ \\
\hline 3 & 72 & 71 \\
5 & 55 & 55 \\
10 & 43 & 43 \\
15 & 38 & 39 \\
\hline
\end{tabular}

[a] Alabama Forestry Commission, 1993.

[b] Hewlett and Douglass, 1968.

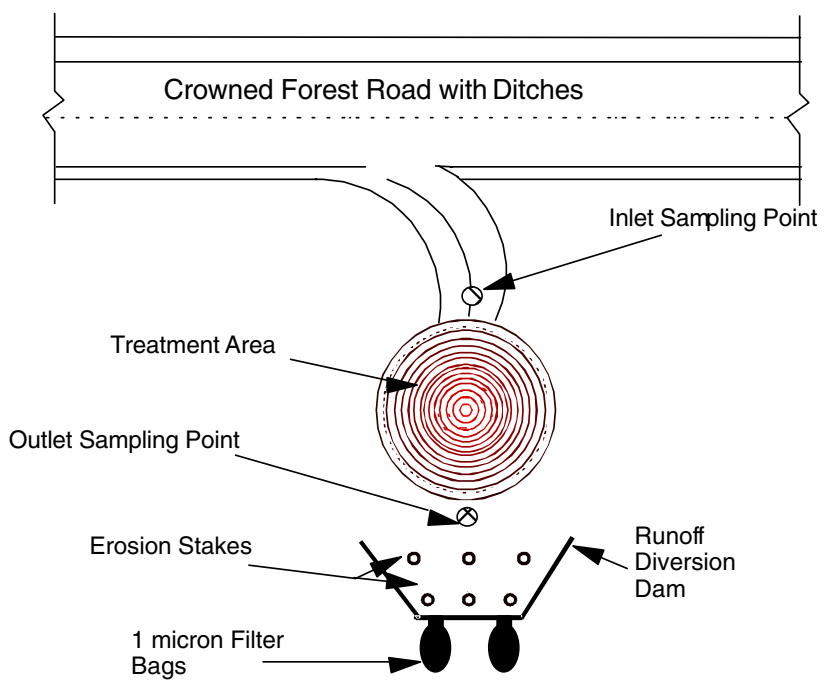

Figure 2. Diagram of individual test area for the Tuskegee study. where

$$
\begin{aligned}
V & =\text { runoff volume }\left(\mathrm{m}^{3}\right) \\
A & =\text { drainage area }\left(\mathrm{m}^{2}\right) \\
d & =\text { depth of rainfall }(\mathrm{m}) .
\end{aligned}
$$

Each basin's design dimensions were $3.5 \mathrm{~m} \times 3 \mathrm{~m} \times 1 \mathrm{~m}$, with a storage capacity of $11 \mathrm{~m}^{3}$. Rip-rap ditch treatments consisted of No. 1 coarse aggregate applied to a thickness of $31 \mathrm{~cm}$ and to a length of $3 \mathrm{~m}$ from the ditch outlet. Sediment fences, $3 \mathrm{~m}$ in length, were placed perpendicular to turn-out ditch outlets for all sediment fence treatments.

Sediment transport from the road prism was measured using two runoff samplers at each turn-out ditch structure located at the inlet and outlet of the mitigation treatments. Composite runoff samples were collected for each runoff event, and suspended sediment was determined by gravimetric filtration. Filtering accomplished by each associated treatment was determined by comparing inflow and outflow runoff concentrations.

Sediment delivery downslope onto the forest floor was also investigated by measuring the quantity of sediment exported to the forest floor downslope of the mitigation treatments. A diversion dam was located below each mitigation treatment to direct runoff into 1-micron filter bags (fig. 2). Filter bags were periodically collected, dried, and weighed. The collected sediment indicated the quantity of sediment that would have been exported into filter strips below each turn-out treatment. Erosion stakes were installed above the diversion dams. Forest floor elevation changes were determined from erosion stakes and were used to estimate the weight of sediment deposited on the forest floor upslope of the filter bags. Total exported sediment was determined as a combination of sediment collected in filter 
bags and sediment deposited on the forest floor above the diversion dam. The procedure ensured collection of nearly $100 \%$ of all sediment passing through treatments. The treatments were then compared on the basis of the total exported sediment.

Inflow and outflow runoff concentration data were analyzed in a paired sample design. Mean reductions between inflow and outflow concentrations were determined and used in analysis of variance (ANOVA). The hypothesis for this comparison was that treatments were equal in capacity to filter sediment-laden runoff. Mean reductions in runoff concentration and sediment yield were used as dependent variables for investigation. Independent variables considered in the ANOVA were treatment method, road grade, and runoff volume. Where ANOVA indicated significant differences, individual treatment means were compared using Duncan's Multiple Range Test.

\section{RESULTS}

Fifty-three sampling events were monitored during this initial phase of the study, which covered a period from 28 August 1997 to 27 December 1998. A sampling event consisted of an individual storm. Storm intensities ranged from 1.0 to $31.0 \mathrm{~mm} /$ hour with an average intensity of $4.4 \mathrm{~mm} /$ hour during the 16-month study period (fig. 3). Inflow and outflow runoff concentrations for each associated erosion control treatment were collected for each rain event. Sediment deposition was measured on four occasions during the study period by collecting sediment bags and measuring sediment deposited on the forest floor.

\section{RunOFF Concentration Reductions}

The reductions in runoff concentration deviated from normality and were normalized with a logarithmic transformation. ANOVA detected significant treatment effects $(p>0.001)$ in the concentration reductions. No significant differences were detected in concentration reductions between vegetation, sediment fence, and settling basin treatments (table 2). Settling basin and rip-rap treatments were statistically similar in capacity to filter sediment laden runoff.

The settling basin and rip-rap treatments were less effective than other treatments at filtering sediment during large storm events $(>40 \mathrm{~mm})$. Runoff during these storms exceeded the design capacity for the settling basins and flushed trapped sediment from the rip-rap treatment. The settling basin was $100 \%$ effective on all but 10 events, but yielded a mean reduction of only 85 over the study period.

\section{Total Exported Sediment}

Sediment export was expected to be least below treatments with the highest reductions in runoff concentrations. No significant treatment differences in mean sediment export or runoff volume were found during the 16-month study period (table 3). Sediment export for vegetation, sediment fence, rip-rap, and settling basin treatments were 43.4, 43.0, 30.1 , and $23.0 \mathrm{~kg}$, respectively.

In an attempt to obtain a better understanding of the sediment export data, a detailed look was taken at the two components measured: sediment deposited on the forest floor, and sediment collected in sediment bags. On average for the four treatments, sediment deposited on the forest floor accounted for more than $93 \%$ of total sediment export for all four treatments. Sediment collected in sediment bags

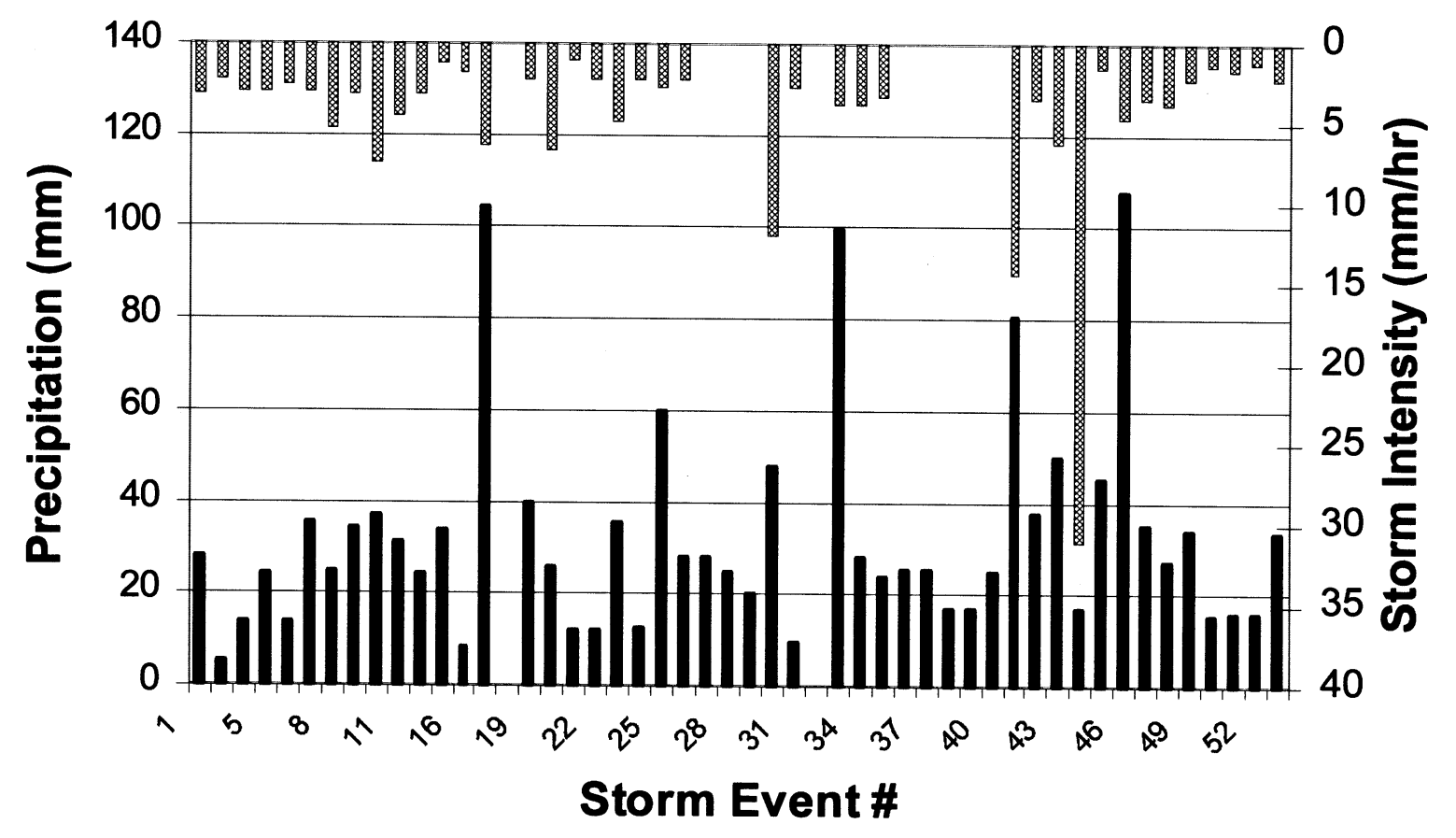

Precipitation Storm Intensity

Figure 3. Observed precipitation and intensity at Tuskegee site during study period. 
accounted for less than $1 \%$ of total sediment export for the settling basin treatment. ANOVA detected significant treatment effects on the sediment bag data collected from each of the treatments. The settling basin and sediment fence yielded significantly less sediment in the sediment bags than the rip-rap and vegetation (table 4). The rip-rap treatment yielded 20 times more sediment in sediment bags than the settling basin during the study period.

\section{DisCUSSION}

Exported sediment that then deposited on the forest floor consisted of the larger soil particles carried in the surface runoff, which requires greater energy to remain suspended. The sediment collected in sediment bags was smaller soil particles easily transported by runoff for longer distances and therefore would more likely reach stream systems. Treatments with greater reductions in sediment deposited in sediment bags will likely reduce the water quality impacts of forest road sediment.

The study soil in this investigation likely had an effect on the measured sediment delivery rates downslope. The loamy sand had a high infiltration rate of $30 \mathrm{~cm} / \mathrm{hr}$, which reduced the total runoff entering the treatment area. The high infiltration rate reduced the erosive energy of the runoff, thereby reducing the sediment transport distances downslope. Reduction of runoff volumes generally reduces the detachment and transport energy of the runoff waters.

Table 2. Mean runoff concentration reductions for treatments during the study period.

\begin{tabular}{lccc}
\hline Treatment & $\mathrm{N}$ & $\begin{array}{c}\text { Mean Inflow } \\
\text { Runoff } \\
\text { Concentration } \\
(\mathrm{ppm})\end{array}$ & $\begin{array}{c}\text { Mean Runoff } \\
\text { Concentration } \\
\text { Reductions }\end{array}$ \\
\hline Vegetation & 48 & 306.1 & (ppm) \\
Sediment fence & 62 & 251.3 & $187.0 \mathrm{a}$ \\
Settling basin & 74 & 142.0 & $183.8 \mathrm{a}$ \\
Rip-rap & 49 & 228.7 & $129.2 \mathrm{ab}$ \\
\hline
\end{tabular}

[a] Means with the same letter indicate no significant difference using Duncan's Multiple Range Test, $\mathrm{P}>0.05$.

Table 3. Sediment export during the study period.

\begin{tabular}{lccccc}
\hline & Sediment & $\begin{array}{c}\text { Total } \\
\text { Export[a] } \\
(\mathrm{kg})\end{array}$ & $\begin{array}{c}\text { Average } \\
\text { Runoff[a] } \\
\left(\mathrm{m}^{3}\right)\end{array}$ & $\begin{array}{c}\text { Flow } \\
\text { Distance } \\
(\mathrm{m})\end{array}$ & $\begin{array}{c}\text { Average } \\
\text { Drainage } \\
\text { Area } \\
\left(\mathrm{m}^{2}\right)\end{array}$ \\
\hline Vegetation & 3 & $43.4 \mathrm{a}$ & $200 \mathrm{a}$ & 60 & 240 \\
Sediment fence & 3 & $43.0 \mathrm{a}$ & $140 \mathrm{a}$ & 50 & 170 \\
Rip-rap & 3 & $30.1 \mathrm{a}$ & $170 \mathrm{a}$ & 60 & 200 \\
Settling basin & 3 & $23.0 \mathrm{a}$ & $150 \mathrm{a}$ & 50 & 180
\end{tabular}

[a] The same letters within a column indicate no significant difference using Duncan's Multiple Range Test, $\mathrm{P}>0.05$.

Table 4. Mean collected sediment bag weights during the study period.

\begin{tabular}{lcc}
\hline Treatment & $\mathrm{N}$ & $\begin{array}{c}\text { Mean Sediment Bag Weight } \\
(\mathrm{kg})\end{array}$ \\
\hline Rip-rap & 3 & $2.23 \mathrm{a}$ \\
Vegetation & 3 & $1.66 \mathrm{a}$ \\
Sediment fence & 3 & $0.64 \mathrm{~b}$ \\
Settling basin & 3 & $0.11 \mathrm{~b}$ \\
\hline
\end{tabular}

[a] Means with the same letter indicate no significant difference using Duncan's Multiple Range Test, $\mathrm{P}>0.05$.
Additional investigations to characterize the effect of erosion control treatments on different soil types are being developed.

In the past 70 years, research has been carried out on sediment transport and erosion control on the traveled way, roadside slopes, and filter strips. The result of this work has spawned most states to recommend BMPs, which involve utilizing erosion control techniques on the road prism and adequate filter strip widths to remove sediment from runoff before reaching waterways. Long-term monitoring of required filter strip widths has not been accomplished by any of the previous work.

The filtering capacity of the forest floor is not boundless and decreases as sediment is deposited from runoff. In time, as the filtering capacity of the forest floor is exhausted, sediment can be delivered to streams, complicating water quality issues. Effective filtering of sediment-laden runoff can be accomplished before runoff reaches the forest floor. Previous work has investigated filter strips used below erosion sources to control erosion losses but has not focused on the roadside ditch and control techniques that can be applied to reduce sediment transport. Research needs to be undertaken to investigate techniques that can be applied to reduce sediment transport onto the forest floor and eventually to streams.

\section{Conclusions}

All four treatments in the investigation resulted in mean runoff concentration reductions greater than $40 \%$ over the study period. ANOVA detected significant treatment effects ( $p>0.001)$ on runoff concentration reductions. No significant differences were found between concentrations from vegetation, sediment fence, and settling basin treatments, or between settling basin and rip-rap. The vegetation and sediment fence treatments, however, yielded greater reductions in runoff concentrations than the rip-rap. Settling basins were very effective for storms smaller than the design storm and appear to hold promise if they can be constructed with enough capacity for most of the storm events.

ANOVA detected no significant differences in total exported sediment below each treatment, but real differences may exist and might be detected if considerably larger sample sizes could be obtained in future studies. The settling basin, which had the greatest retention time for runoff, had less sediment export below the treatment than all other treatments in the experiment. The rip-rap treatment also had a relatively low sediment export in comparison to the sediment fence and vegetation treatments.

\section{REFERENCES}

Alabama Forestry Commission. 1993. Alabama's best management practices for forestry. Montgomery, Ala.: Alabama Forestry Commission.

Anderson, H. W., M. D. Hoover, and K. G. Reinhart. 1976. Forest and water: Effects of forest management on floods, sedimentation, and water supply. General Technical Report PSW-18. San Francisco, Cal.: USDA Forest Service.

Brinker, R. W. 1993. Best management practices for timber harvesters. Alabama Cooperative Extension Service, Agriculture 
and Natural Resources, Circular ANR-539. Auburn, Ala.: Auburn University.

Binkley, D., and T. C. Brown. 1993. Forest practices as nonpoint sources of pollution in North America. Water Resources Bulletin 29(5): 729-740.

Cook, W. L., Jr., and J. D. Hewlett. 1979. The broad-based dip on Piedmont woods roads. Southern J. Applied Forestry 3(1): $77-81$.

Gardner, R. B. 1978. Some environmental and economic effects of alternative forest road designs. Trans. ASAE 22(1): 63-68.

Grace, J. M., III. 1998. Sediment export from forest road turn-outs: A study design and preliminary results. ASAE Paper No. 987026. St. Joseph, Mich.: ASAE.

1999. Erosion control techniques on forest road cutslopes and fillslopes in North Alabama. In Seventh International Conference on Low-Volume Roads: Vol. 2. Transportation Research Record 1652, 227-234. Washington, D.C.: National Research Council, Transportation Research Board.

Grace, J. M., III, B. Rummer, and B. J. Stokes. 1997. Sediment production and runoff from forest road sideslopes. ASAE. Paper No. 975019. St. Joseph, Mich.: ASAE.

Grace, J. M., III, B. Rummer, B. J. Stokes, and J. Wilhoit. 1998. Evaluation of erosion control techniques on forest roads. Trans. ASAE 41(2): 383-391.

Haupt, H. F. 1959. Road and slope characteristics affecting sediment movement from logging roads. J. Forestry 57(5): 329-332.

Hewlett, J. D., and J. E. Douglass. 1968. Blending forest uses. Research Paper SE-37. Asheville, N.C.: USDA Forest Service.

Hoover, M. D. 1952. Water and timber management. J. Soil and Water Conservation 7(2): 75-78.

Megahan, W. F. 1972. Logging, erosion, sedimentation: Are they dirty words? J. Forestry 70(5): 403-407.
McClelland, D. E., R. B. Foltz, C. M. Falter, W. D. Wilson, T. Cundy, R. L. Schuster, J. Saurbier, C. Rabe, and R. Heinemann. 1999. Relative effects on a low-volume road system of landslides resulting from episodic storms in Northern Idaho. In Seventh International Conference on Low-Volume Roads: Vol. 2. Transportation Research Record 1652, 235-243. Washington, D.C.: National Research Council, Transportation Research Board.

Murphy, A. A. 1985. Minimizing forest road construction environmental impact. Presented at the New England Regional Council on Forest Engineering. NER.COFE Roads and Structures Workshop, 5-10. March 21-22. Orono, Maine: University of Maine.

Packer, P. E. 1967. Criteria for designing and locating logging roads to control sediment. Forest Science 13(1): 2-18.

Patric, J. H. 1976. Soil erosion in the eastern forest. J. Forestry 74(10): 671-677.

Reid, L. M., and T. Dunne. 1984. Sediment production from forest road surfaces. Water Resources Research 20(11): 1753-1761.

Reinhart, K. R., A. R. Eschner, and G. R. Trimble, Jr. 1963. Effect of streamflow of four forest practices in the mountains of West Virginia. Research Paper NE-1. Upper Darby, Pa.: USDA Forest Service.

Swift, L. W., Jr. 1985. Forest road design to minimize erosion in the southern Appalachians. In Proc. Forestry and Water Quality: A Mid-South Symposium, 141-151. B. G. Blackman, ed. May 8-9. Little Rock, Ark.: University of Arkansas, Montecello School of Forestry.

1986. Filter strip widths for forest roads in the southern Appalachians. Southern J. Applied Forestry 10(1): 27-34.

Trimble, G. R., Jr., and R. S. Sartz. 1957. How far from a stream should a logging road be located? J. Forestry 55(5): 339-342.

Weitzman, S., and G. R. Trimble, Jr. 1952. Skid-road erosion can be reduced. J. Soil and Water Conservation 7(3): 122-124. 